\title{
ANTIOXIDANT ACTIVITY AND ANTIPROLIFERATIVE ACTION OF METHANOLIC EXTRACT OF LIQUORICE (GLYCYRRHIZA GLABRA) IN HEPG2 CELL LINE
}

\author{
DASHARATH B. SHINDE, SANTOSH S. KORATKAR*, NEETI SHARMA, AJINKYA A. SHITOLE \\ Symbiosis School of Biomedical Sciences, Symbiosis International University, Gram-Lavale; Taluka-Mulshi, Pune, India \\ Email: santosh.koratkar@gmail.com
}

Received: 31 Mar 2016 Revised and Accepted: 20 Jun 2016

\section{ABSTRACT}

Objective: To evaluate the in vitro antioxidant activity of liquorice (Glycyrrhiza glabra) against $\mathrm{H}_{2} \mathrm{O}_{2}$ induced oxidative stress in HepG2 cell line.

Methods: Antioxidant activity of methanolic extracts of Glycyrrhiza glabra was investigated by measuring total phenolic content using folinciocalteu reagent (FCR), free radical scavenging activity by DPPH and ferric reducing antioxidant power (FRAP). The presence of phenolic compounds and flavonoids in the extract was confirmed by Liquid Chromatography-Mass Spectrometry (LC-MS) analysis. Furthermore, the protective effect of methanolic extract of Glycyrrhiza glabra against oxidative stress induced by $\mathrm{H}_{2} \mathrm{O}_{2}$ in HepG2 cells was investigated by MTT assay. HepG2 cells were exposed with five different treatments viz. liquorice, $\mathrm{H}_{2} \mathrm{O}_{2}$, ascorbic acid, $\mathrm{H}_{2} \mathrm{O}_{2}+$ liquorice and $\mathrm{H}_{2} \mathrm{O}_{2}$ +ascorbic acid, to explore the effect of the extract on malondialdehyde (MDA) production, catalase activity, and glutathione reductase levels.

Results: The total phenolic content estimated in Glycyrrhiza glabra extract was found to be $241.47 \mu \mathrm{g}$ per $1000 \mu \mathrm{g} / \mathrm{ml}$ of methanolic extract. It was found that as the concentration of the extract was increased both the free radical scavenging activity and ferric ion reducing power was also found to increase. LC-MS analysis confirmed the presence of eight different phenolic compounds in the methanolic extract which are possibly contributing to the antioxidant activity exhibited by the extract. It was also observed that liquorice treated HepG2 cells showed lower MDA and higher glutathione and catalase levels as compared to only $\mathrm{H}_{2} \mathrm{O}_{2}$ treated $\mathrm{HepG} 2$ cells where increased MDA production, decreased glutathione reductase and catalase production was observed.

Conclusion: Our results thus conclude that, the methanolic extract of Glycyrrhiza glabra can be used as natural supplements in various disease conditions where oxidative stress has been reported.

Keywords: Liquorice, Oxidative stress, $\mathrm{H}_{2} \mathrm{O}_{2}$, HepG2 cells, Antioxidant activity, Free radicals, MDA, SOD, Catalase

(C) 2016 The Authors. Published by Innovare Academic Sciences Pvt Ltd. This is an open access article under the CC BY license (http://creativecommons. org/licenses/by/4. 0/) DOI: http://dx.doi.org/10.22159/ijpps.2016v8i9.11954

\section{INTRODUCTION}

Liquorice is a general herb of the Asian region and is commonly used in the diet. Roots of liquorice have been found to be useful due to its pharmacological properties such as anti-inflammatory, anticarcinogenic, antiallergic, antimutagenic, antimicrobial, antiulcer activity along with cardioprotective, hepatoprotective and immune modulatory effects $[1,2]$. Many studies have shown that the consumption of fruits and vegetables is associated with a reduced risk of developing chronic diseases, such as coronary heart diseases, cancer, diabetes and Alzheimer's disease. The protective effect of these foods is attributed to the presence of phytochemical compounds such as carotenoids, tocopherols, and polyphenols [3]. The yellow color of liquorice is due to high flavonoid content of the plant, which includes liquiritin, isoliquiritin (a chalcone) and other compounds responsible for its antioxidant activity. The isoflavones glabridin and hispaglabridins A and B have been reported to exhibit significant antioxidant activity [1]. Increase in oxidative stress as observed in lifestyle diseases and increasing use of allopathic medicines and chemical compounds there is an immediate need of identification of alternatives which can alleviate the altered health conditions [4].

Phytochemicals especially polyphenols constitute a major group of compounds that act as active antioxidants. They are known to act as antioxidants not only because of their ability to donate hydrogen or electrons but also because of their stable radical intermediate activity [5]. The reported phytochemical studies showed that liquorice roots contain a saponin such as glycyrrhizin which is 60 times sweeter than cane sugar [6].

Many factors are responsible for inducing oxidative stress and enhancing production of free radicals such as radiation or exposure to heavy metals and xenobiotics. Reported literature also indicate that $\mathrm{H}_{2} \mathrm{O}_{2}$ induced oxidative stress leads to lipid peroxidation and causes cell damage because of its half-life is longer than that of other reactive oxygen species (ROS) and it can easily transformed into a hydroxyl radical, which is one of the most destructive free radical $[7,29]$.

ROS production is a well-established physiological process which is controlled by the intrinsic system of antioxidants. Particularly liver is susceptible to toxic and oxidative insults because the portal vein brings blood to this organ after intestinal absorption. In a concentrated form absorbed drugs and xenobiotics can cause free radicals and ROS production which mediate damage that may result in inflammatory and fibrotic processes $[8,9]$.

The present study reports for the first time the investigation of the antioxidant properties of liquorice in an in vitro model viz. HepG2 cells.

\section{MATERIALS AND METHODS}

\section{Chemicals and reagents}

All the chemicals required in the study were purchased from Sigma: (DPPH), HiMedia: (Potassium ferricyanide, TBA, NADH, Ellmans reagent, Glutathione, MEM, TPVG, Antibiotics: Penicillin and Streptomycin solution, PBS, TBA), MERCK: (DMSO, Potassium chloride), Fisher Scientific: (Methanol, Ascorbic acid), SRL: (TCA, Ferric chloride, Sodium chloride Meta-phosphoric acid, Phenazine methosulphate, Tetrasodium pyrophosphate)

\section{Preparation of plant extract}

Liquorice roots were procured from the Department of Agricultural Botany, Mahatma Phule Krishi Vidyapeeth, Rahuri, Maharashtra, India. Roots were washed with water and dried in the shade. The dried plant material was then blended into powder using an electric blender, $250 \mathrm{gm}$ of dry powder was mixed with $500 \mathrm{ml}$ of methanol, and the mixture was filtered through Whatman filter paper No.1. The filtrate was collected in a new sterile flask, and the extracts were concentrated using a rotary evaporator and was stored at refrigerator for further experiments. 


\section{Determination of total phenolic content}

Total phenolic constituents of plant extracts was performed as described earlier $[5,10]$ which involves folin-ciocalteu reagent and ascorbic acid as standard. About $1.0 \mathrm{ml}$ of plant extract $(5 \mu \mathrm{g} / \mathrm{ml}$ to $1000 \mu \mathrm{g} / \mathrm{ml}$ ) was taken in a test tube. Then $5 \mathrm{ml}$ of folin-ciocalteu (diluted 10 fold) reagent solution and $4 \mathrm{ml}$ of sodium carbonate solution $(7.5 \%)$ was added into the test tube. The test tube was incubated for $30 \mathrm{~min}$ at $20^{\circ} \mathrm{C}$ to complete the reaction. Absorbance was measured at $765 \mathrm{~nm}$ using spectrophotometer against blank. The total content of phenolic compounds in methanol plant extracts was calculated as ascorbic acid equivalents.

\section{Free radical scavenging activity by DPPH}

Free radical scavenging activity of the extract was evaluated in vitro by 2, 2-diphenyl-1-picrylhydrazyl (DPPH) assay according to the method described by Hatano T. et al., 1989 and Neeti S. et al., 2014 with some modifications $[11,12]$. DPPH solution was prepared by dissolving $24 \mathrm{mg}$ DPPH in $100 \mathrm{ml}$ methanol and stored at $-20^{\circ} \mathrm{C}$ till further use. $150 \mu \mathrm{l}$ of this DPPH solution was mixed with $50 \mu \mathrm{l}$ of the methanolic extract at various concentrations $25 \mu \mathrm{g} / \mathrm{ml}$ to 1000 $\mu \mathrm{g} / \mathrm{ml}$. The reaction mixture was mixed well and incubated in the dark for $30 \mathrm{~min}$. The absorbance was measured at $517 \mathrm{~nm}$ using an ELISA plate reader. Blank was prepared without adding methanolic extract. The scavenging activity was calculated using the following formula based on the percentage of DPPH radical scavenged.

$$
\text { Percent of inhibition }=\frac{\text { Blank }- \text { Sample }}{\text { Blank }} \times 100
$$

\section{Ferric reducing antioxidant power (FRAP)}

Antioxidant activity of the extract was measured as described by Asan M. and Karakoca, 2013 with few modifications [13]. Briefly, 40 $\mu \mathrm{l}$ of methanolic plant extracts at various concentrations (1-10 $\mathrm{mg} / \mathrm{ml}$ ) was mixed with $100 \mu \mathrm{l}$ of $0.2 \mathrm{M}$ phosphate buffer ( $\mathrm{pH}$ 6.6) and $100 \mu \mathrm{l}$ of potassium ferricyanide $(1 \%)$. After incubation at $50{ }^{\circ} \mathrm{C}$ for $20 \mathrm{~min}, 100 \mu \mathrm{l}$ of $10 \%$ trichloroacetic acid (TCA) were added to the mixture followed by centrifugation at $10,000 \mathrm{rpm}$ for $10 \mathrm{~min}$ to stop the reaction. $100 \mu \mathrm{l}$ of the collected upper layer of the mixture was mixed with $100 \mu \mathrm{l}$ of distilled water, and $20 \mu \mathrm{l}$ of ferric chloride $(0.1 \%)$ and the absorbance of the resulting solution was read at 700 $\mathrm{nm}$ against a blank. Ascorbic acid was used as positive control.

\section{Liquid chromatography-mass spectrometry (LC-MS)}

Identification of major phenolic compounds in the extracts was carried out using LC-MS method as described by Ibrahim K. et al,, (2010) with few modifications [14]. Briefly $1 \mathrm{mg}$ root extract was suspended in methanol and dissolved thoroughly and centrifuged at $10,000 \mathrm{rpm}$ for $10 \mathrm{~min} .20 \mu \mathrm{l}$ of the supernatant was suspended in $980 \mu \mathrm{l}$ of MS grade methanol and used to perform LC-MS analysis. All the solvents used for LC-MS analysis were of MS grade. The LCMS analysis was performed using thermo qExactive orbitrap mass spectrometry equipped with accela 1250 UHPLC systems. Separation of compounds was achieved using a reverse phase Thermo C-18 column $(200 \mathrm{~mm} \times 2.1 \mu \times 1.9 \mu)$ and mobile phases with a gradient of water and acetonitrile. Data acquisition of the sample was done in a positive mode of ionization to obtain the chromatogram and the spectra. Using the obtained spectra, the identification of the compounds was performed.

\section{Maintenance of cell line}

The human hepatoma cell line HepG2 was procured from National Center for Cell Science (NCCS), Pune. Cells passaging was done every third day after cells were at least $80 \%$ confluent as per the method described by Jiying J. et al., 2014 [15]. Cells were incubated in a humidified atmosphere and $5 \% \mathrm{CO}_{2}$ in a $37{ }^{\circ} \mathrm{C}$ incubator with minimum essential medium (MEM) supplemented with $10 \%$ heatinactivated fetal bovine serum (FBS), $100 \mu \mathrm{g} / \mathrm{ml}$ streptomycin, and $100 \mathrm{U} / \mathrm{ml}$ of penicillin.

\section{Determination of cytotoxicity of plant extracts by MTT assay}

MTT assay was carried out as per the method described by Jiying J. et al., 2014 [15]. $2 \times 10^{5} \mathrm{HepG} 2$ cells per well were cultured in 96 well microtiter plates in a final volume of $100 \mu \mathrm{l}$ culture medium MEM (containing 10\% FBS) per well. After incubation for $24 \mathrm{~h}$ at $37^{\circ} \mathrm{C}$ and $5 \% \mathrm{CO}_{2}$, when a confluent monolayer was formed, the medium was removed, washed once with plane medium (MEM without serum) and $100 \mu \mathrm{l}$ different concentrations of methanolic extract of liquorice $(10-100 \mu \mathrm{g})$ were added to each well and the plate was again incubated for $24 \mathrm{~h} .20 \mu \mathrm{l}$ of MTT in phosphate buffer saline (PBS) solution $(1 \mathrm{mg} / \mathrm{ml})$ was added to each well and the plate was further incubated for $4 \mathrm{~h}$ in the dark after incubation MTT was removed and $100 \mu \mathrm{l}$ of dimethyl sulphoxide (DMSO) was added into each well to solubilize the formazan crystals. The absorbance was measured at $490 \mathrm{~nm}$ using an ELISA plate reader. Cell viability against $\mathrm{H}_{2} \mathrm{O}_{2}$ and ascorbic acid was determined using the same protocol. Further, $\mathrm{H}_{2} \mathrm{O}_{2}$ treated cells were treated with different concentration of the liquorice and effect of methanolic extract of liquorice was then evaluated. The percent growth inhibition was calculated using the following formula.

$$
\text { Cell viability }(\%)=\frac{\text { Absorbance of experimental group }}{\text { Absorbance of Blank }} \times 100
$$

\section{Determination of MDA}

Cell lysates of treated and control groups were prepared in 1X PBS. MDA levels were estimated by the double heating method of Draper and Hadley as followed by Kerman M. and Nilgun S. 2012 [16]. $2.5 \mathrm{ml}$ of 100 $\mathrm{g} / \mathrm{l}$ trichloroacetic acid (TCA) solution was added to $0.5 \mathrm{ml}$ cell lysate in each centrifuge tube and the tubes were placed in a boiling water bath for $15 \mathrm{~min}$. After cooling in tap water, the tubes were centrifuged at 1000 $\mathrm{g}$ for $10 \mathrm{~min}$ and $2 \mathrm{ml}$ of the supernatant was added to $1 \mathrm{ml}$ of $6.7 \mathrm{~g} / \mathrm{l}$ thiobarbituric acid (TBA) solution in a test tube and the tube was placed in a boiling water bath for $15 \mathrm{~min}$. The solution was then cooled in tap water, and its absorbance was measured using a spectrophotometer (Shimadzu UV-1601, Japan) at $532 \mathrm{~nm}$. The concentration of MDA was calculated by the absorbance coefficient of the MDA-TBA complex (absorbance coefficient $=$ Absorbance $/ 1.56 \times 10^{5} / \mathrm{cm} / \mathrm{M}$ ) and was expressed as nM/g units wet tissue.

\section{Glutathione reductase assay}

Glutathione reductase activity was determined by a colorimetric assay described by Akerboom TP and Sies H 1981 [17]. In short $2.5 \mathrm{ml}$ of metaphosphoric acid (1.67 g glacial metaphosphoric acid; $0.2 \mathrm{~g}$ of EDTA, and $30 \mathrm{~g}$ of $\mathrm{NaCl}$ in $100 \mathrm{ml}$ of deionized water) was mixed with $1.5 \mathrm{ml}$ of distilled water and $0.5 \mathrm{ml}$ of sample mixed well and $1 \mathrm{ml}$ of mixture was taken in new tube and mixed with $4 \mathrm{ml}$ of $\mathrm{Na}_{2} \mathrm{HPO}_{4}$. Then $0.5 \mathrm{ml}$ of dithio-bisnitro benzoic acid (DTNB) was added and the reaction mixture was mixed properly. Blank was prepared without addition of cell lysate and absorbance was recorded at $412 \mathrm{~nm}$.

\section{Catalase activity}

Catalase activity was determined in freshly sonicated extracts of cells treated with $\mathrm{H}_{2} \mathrm{O}_{2}$, liquorice and ascorbic acid as described by Jingxiang B et al., 1999 [18]. Decomposition of hydrogen peroxide by catalase was followed by ultraviolet spectroscopy at $230 \mathrm{~nm}$, at different time intervals from 30 to $180 \mathrm{~s}$.

\section{Statistical analysis}

All experiments were carried out in at least 3 replicates. One-way ANOVA was applied to determine the significance of results between different treatments. Statistical analysis was carried out using Graph Pad Prism 5 for Windows version 5.03. $p \leq 0.05$ was considered to be statistically significant.

\section{RESULTS}

Liquorice extract was evaluated for its antioxidant activity and cytotoxicity in HepG2 cell line by various in vitro assays. The total phenolic content of the methanolic extract of liquorice was measured using the folin-ciocalteu method, and it was found that $241.47 \mu \mathrm{g}$ of total phenolic compounds was present in $1000 \mu \mathrm{g} / \mathrm{ml}$ of methanolic extract of liquorice.

The free radical scavenging activity of liquorice was assessed by DPPH method and compared with standard antioxidant ascorbic acid. It was observed that the free radical scavenging activity of liquorice 
increased as its concentration was increased with respect to ascorbic acid which was used as a standard fig. 1(A). Ferric ion reducing power of liquorice extract was also found to increase in a similar way as the reducing power of ascorbic acid increased fig. 1(B).
$\mathbf{A}$

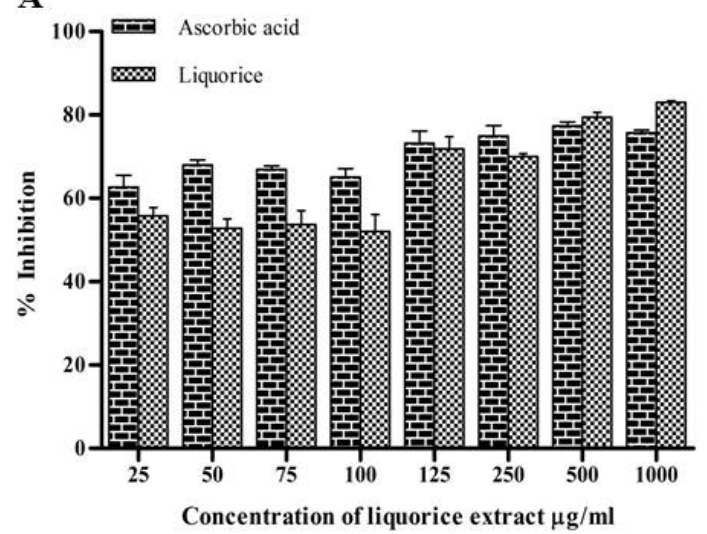

B

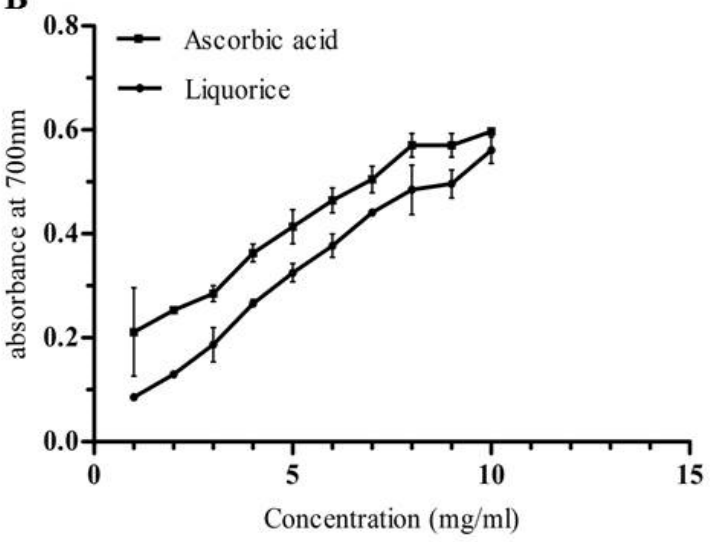

Fig. 1: A. Free radical scavenging activity of liquorice as compared with standard ascorbic acid measured by DPPH assay; $B$. Ferric reducing the antioxidant power of liquorice measured and compared with standard ascorbic acid. All the values are expressed as mean $\pm S E M, n=3$

Table 1: List of eight different phenolic group compounds identified in the methonolic extract of liquorice by LC-MS analysis (Abbreviations: $\mathrm{m} / \mathrm{z}=$ mass/charge ratio, Sr. No = serial number, $\mathrm{gm} / \mathrm{mol}=$ grams per mole)

\begin{tabular}{|c|c|c|c|c|c|c|}
\hline Sr. No. & Phenolic compounds & Molecular formula & Molecular mass gm/mol & Retention time (RT) min & m/z ratio & References \\
\hline 1 & Liquiritin & $\mathrm{C}_{21} \mathrm{H}_{22} \mathrm{O}_{9}$ & 418.39 & 10.77 & 419.30 & 24 \\
\hline 2 & Isolquiritin & $\mathrm{C}_{21} \mathrm{H}_{22} \mathrm{O}_{9}$ & 418.39 & 10.77 & 419.30 & 24 \\
\hline 3 & Liquiritigenin & $\mathrm{C}_{15} \mathrm{H}_{12} \mathrm{O}_{4}$ & 256.25 & 11.56 & 257.08 & 24 \\
\hline 4 & Formonetin & $\mathrm{C}_{15} \mathrm{H}_{12} \mathrm{O}_{4}$ & 268.26 & 11.81 & 269.08 & 4,24 \\
\hline 5 & Hispaglabridin-B & $\mathrm{C}_{25} \mathrm{H}_{26} \mathrm{O}_{4}$ & 390.41 & 13.09 & 391.19 & 4,24 \\
\hline 6 & Glabridin & $\mathrm{C}_{20} \mathrm{H}_{20} \mathrm{O}_{4}$ & 324.37 & 15.92 & 325.14 & 24,25 \\
\hline 7 & Glabrol & $\mathrm{C}_{25} \mathrm{H}_{28} \mathrm{O}_{4}$ & 329.49 & 16.60 & 393.20 & 4,24 \\
\hline 8 & Glycyrrhizin & $\mathrm{C}_{42} \mathrm{H}_{62} \mathrm{O}_{16}$ & 822.94 & 16.28 & 823.41 & 4,24 \\
\hline
\end{tabular}

Methanolic extract of liquorice was analyzed using LCMS which confirmed the presence of eight different phenolic compounds (fig. 2) (table. 1) which are known for their antioxidant activity.

A

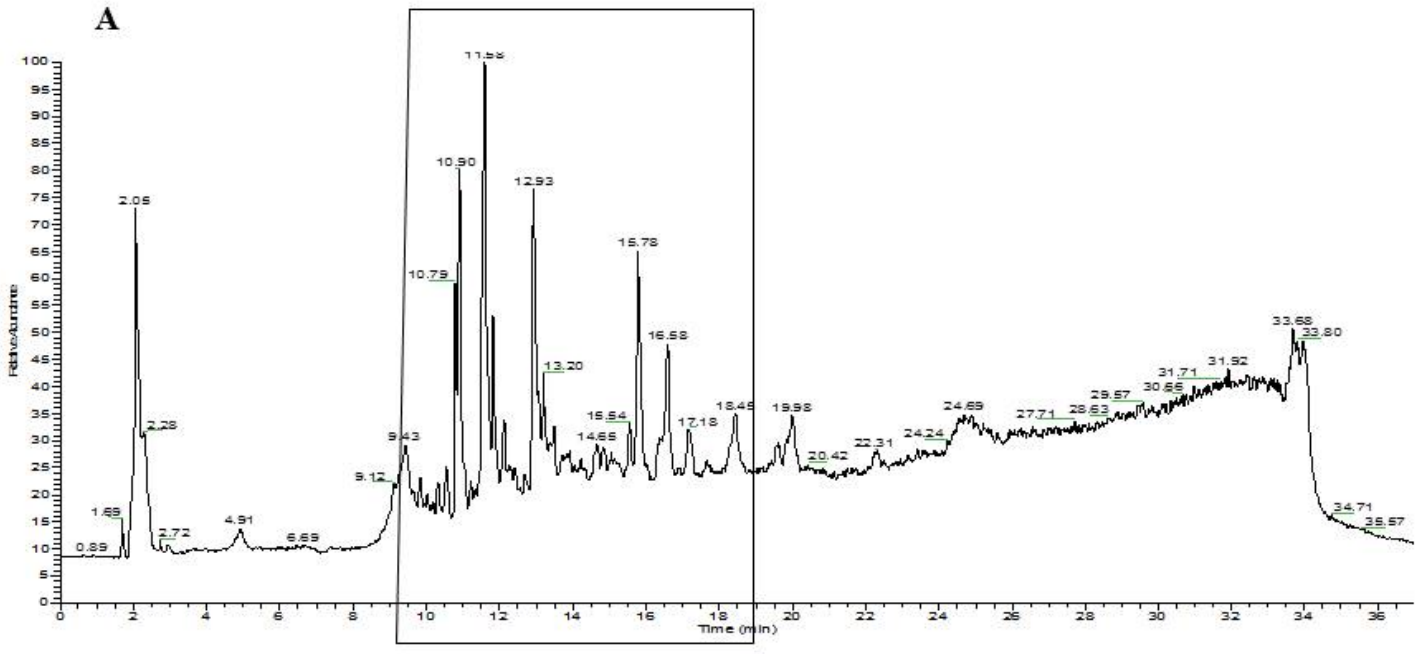

Fig. 2A: LC-MS chromatograms representing different phenolic compounds presents in the methanolic extract of liquorice

$\mathrm{H}_{2} \mathrm{O}_{2}$ is already known for its oxidant activity, and it tends to induce oxidative stress in the cells. To determine whether liquorice inhibits the $\mathrm{H}_{2} \mathrm{O}_{2}$-induced cell death in $\mathrm{HepG} 2$ cells MTT assay was performed by treating the cells with different concentration of $\mathrm{H}_{2} \mathrm{O}_{2}$
(50 to $100 \mu \mathrm{M}$ ) for $2 \mathrm{~h}$. The viability of HepG2 was found to decrease by about $50 \%$ at the concentration of $30 \mu \mathrm{M} \mathrm{H} \mathrm{H}_{2} \mathrm{O}_{2}$ fig. 3(A). Therefore we exposed HepG2 cells to a concentration of $30 \mu \mathrm{M} \mathrm{H}_{2} \mathrm{O}_{2}$ for $2 \mathrm{~h}$ to induce oxidative stress for further experiments. 

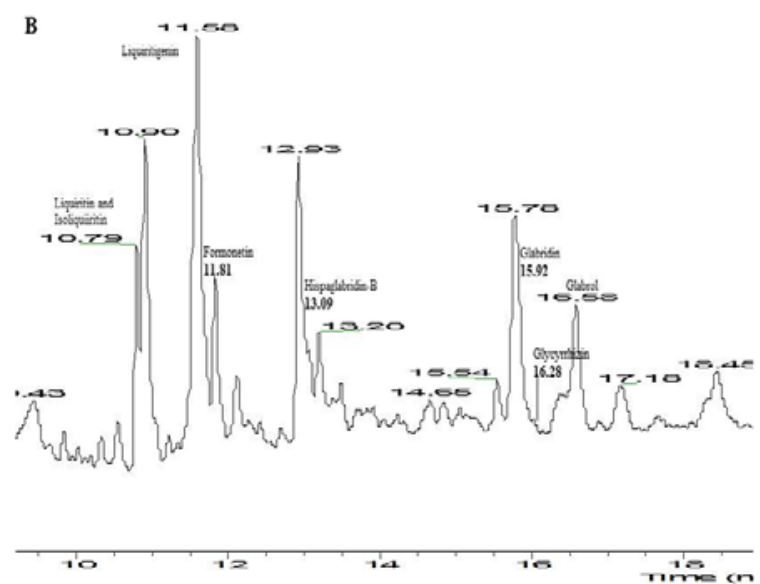

Fig. 2B: Enlarge form of square section of fig 2A representing eight different phenolic compounds presents in the methanolic extract of liquorice
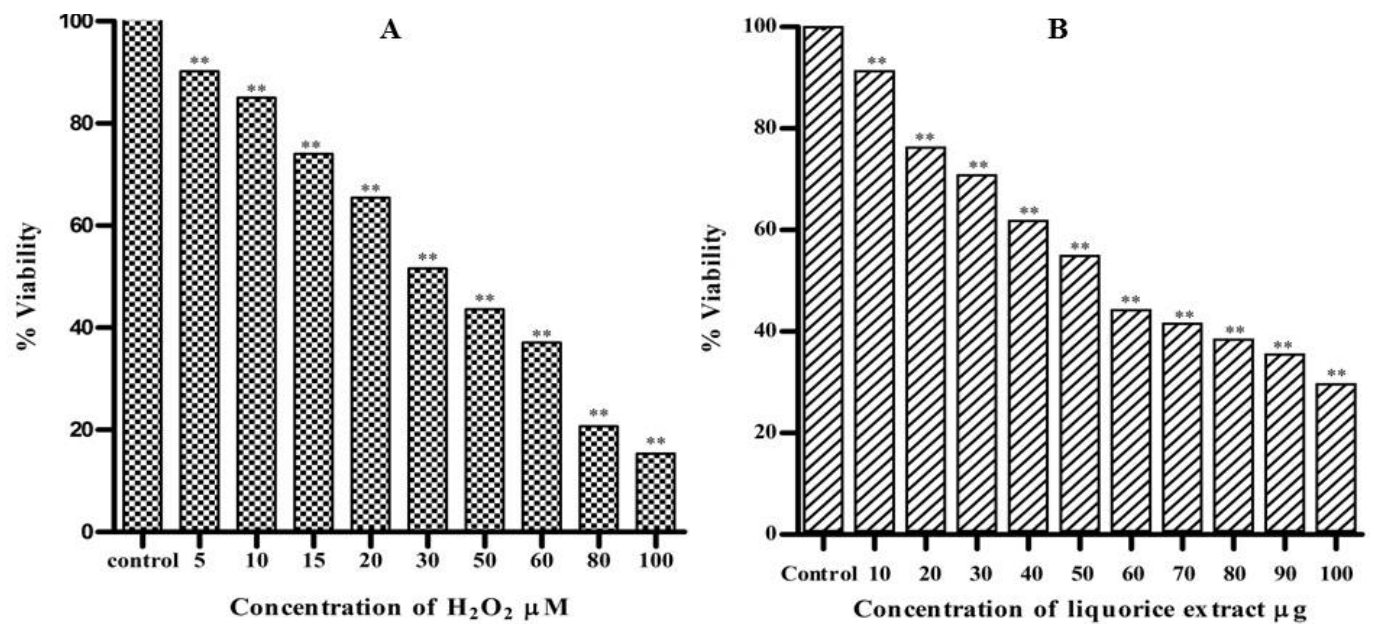

Fig. 3: A. MTT assay of HepG2 cells treated with different concentrations of $\mathrm{H}_{2} \mathrm{O}_{2}(5,10,15,20,30,50,60,80$ and $100 \mu \mathrm{M})$; B. HepG2 cells treated with different concentrations of liquorice $(10,20,30,40,50,60,70,80,90$ and $100 \mu \mathrm{g})$. All the values are expressed as mean \pm SEM, $n=3 .(* * p<0.01)$

To evaluate the most effective concentration of liquorice, HepG2 cells were treated with different concentration of liquorice (10-100 $\mu \mathrm{g})$, and found cell viability decreased by about $50 \%$ [15] at the concentration of $60 \mu \mathrm{g}$ fig. 3(B) which was used for further experiments.

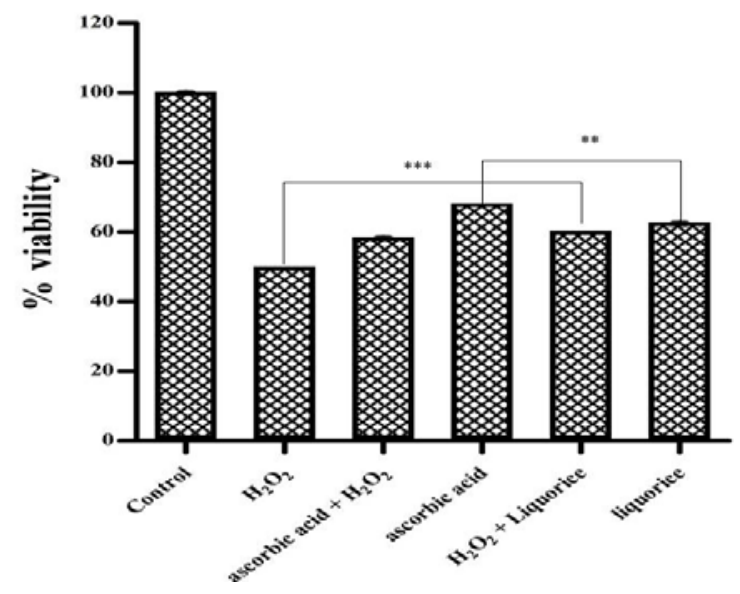

Fig. 4: MTT assay cells treated with treated with $30 \mu \mathrm{M} \mathrm{H}_{2} \mathrm{O}_{2}, 60$ $\mu \mathrm{g}$ of liquorice and $60 \mu \mathrm{g}$ of ascorbic acid. Comparative effect of $\mathrm{H}_{2} \mathrm{O}_{2}$ with $\mathrm{H}_{2} \mathrm{O}_{2}+$ liquorice and liquorice with ascorbic acid as a standard was determined in HepG2 cells. All the values are expressed as mean $\pm S E M, n=3,\left({ }^{* *} p<0.01,{ }^{* * *} p<0.001\right)$
The viability of HepG2 cells in the presence of liquorice or in response to $\mathrm{H}_{2} \mathrm{O}_{2}$ was studied and was compared with standard ascorbic acid. The cell viability of liquorice treated group was found to be almost similar to the standard ascorbic acid. Similar protective effect of liquorice was also found to increase significantly in the presence of $\mathrm{H}_{2} \mathrm{O}_{2}$ (fig. 4).

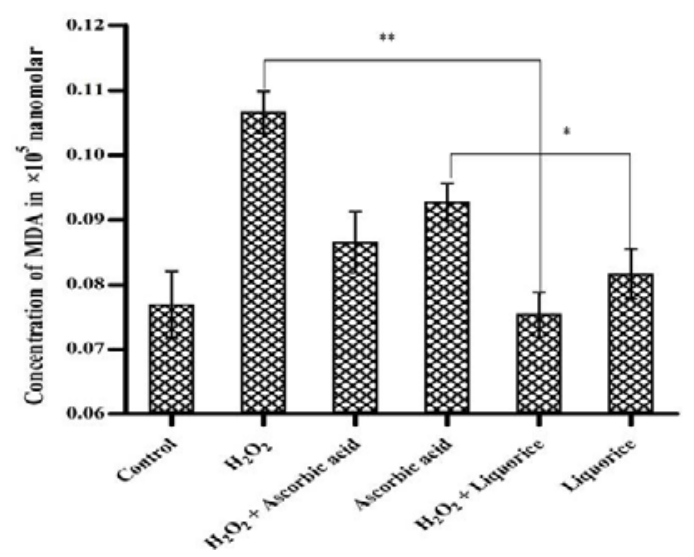

Fig. 5: MDA assay: effect of liquorice extract on MDA production in $\mathrm{HepG} 2$ cells treated with $\mathrm{H}_{2} \mathrm{O}_{2}$ as compared with standard ascorbic acid. All the values are expressed as mean $\pm S E M, n=3$. $\left({ }^{*} \mathbf{p}<0.05, * * \mathbf{p}<0.01\right)$ 
Malondialdehyde (MDA) is an organic compound which is the end product of the lipid peroxidation of polyunsaturated fatty acids known to induce oxidative stress $[19,20]$. The level of lipid peroxidation in liquorice treated cells was evaluated and it was found that the level of lipid peroxidation declined significantly in liquorice treated cells as compared to $\mathrm{H}_{2} \mathrm{O}_{2}$ treated cells (fig. 5).

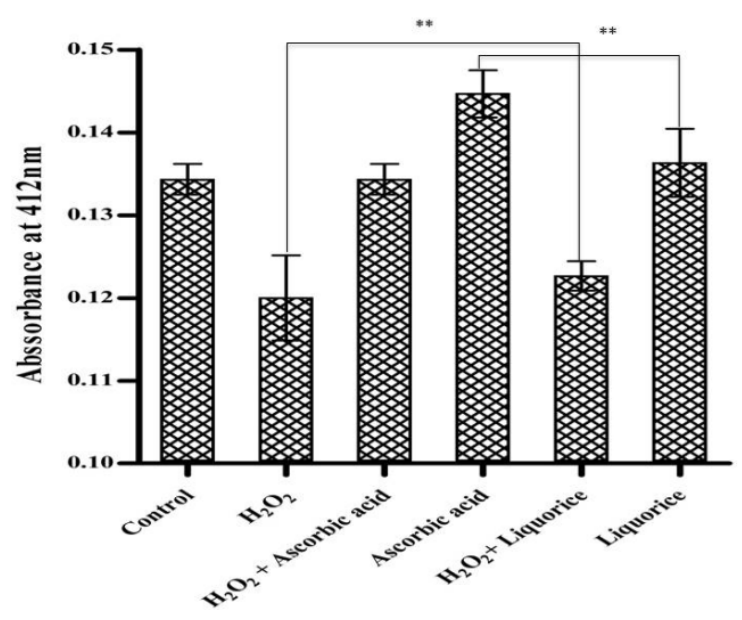

Fig. 6: Glutathione reductase activity of liquorice extract in HepG2 cells treated with $\mathrm{H}_{2} \mathrm{O}_{2}$ as compared with standard ascorbic acid. All the values are expressed as mean $\pm S E M, n=3$, $(* * \mathbf{p}<0.01)$

Glutathione reductase is an antioxidant enzyme which is responsible for the detoxification process reduces oxidative stress and maintains the reducing environment of the cell [21, 22]. Hence the levels of enzyme glutathione reductase were evaluated in the presence of liquorice and it was found that glutathione reductase levels increased in liquorice treated cells as compared to $\mathrm{H}_{2} \mathrm{O}_{2}$ treated cells (fig. 6).

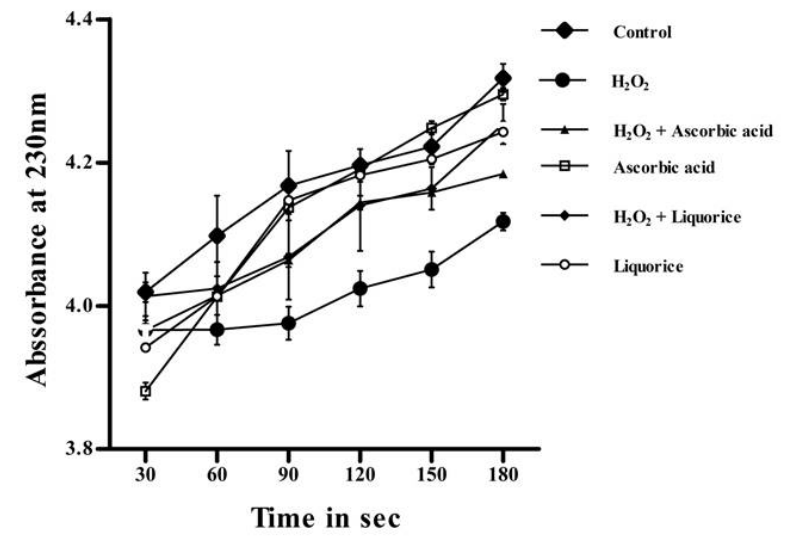

Fig. 7: Catalase activity of liquorice extract in HepG2 cells treated with $\mathrm{H}_{2} \mathrm{O}_{2}$ as compared with standard ascorbic acid. All the values are expressed as mean $\pm S E M, n=3$

Catalase is an antioxidant enzyme. The level of catalase also determined in the presence of $\mathrm{H}_{2} \mathrm{O}_{2}$ and it was found that there was a reduction in catalase production in $\mathrm{H}_{2} \mathrm{O}_{2}$ treated cells. However, it significantly increased in liquorice treated cells (fig. 7).

\section{DISCUSSION}

Many studies have constantly shown that the consumption of fruits and vegetables is associated with a reduced risk of developing chronic diseases, such as coronary heart diseases, cancer, diabetes and Alzheimer's disease $[3,28]$. The protective effect of these foods is attributed to the presence of phytochemical compounds such as carotenoids, tocopherols and polyphenols provided with antioxidant properties. Gupta VK. 2006 [22] reported that the plant extract is an ayurvedic source, and it does not have a side effect on humans.

It is a known fact that the root of Glycyrrhiza glabra is one of the richest sources of biological active compounds such as phenolic and flavonoid compounds which are act as primary antioxidants or free radical scavengers [2, 23]. Several investigations [10, 13] have revealed the presence of a variety of bioreactive polyphenols in liquorice extract which was confirmed by our results of total phenol content assay, DPPH assay, reducing power assay and LC-MS. In the present study, the antioxidant activity of methanolic extract of Glycyrrhiza glabra was evaluated by various biochemical and in vitro assays. The total phenolic content of liquorice methanolic extract was estimated by the folin-ciocalteu method and was found to be $241.47 \mu$. The presence of phenolic compounds such as flavonoids, alkaloids, saponins, tannins, phenols indicates that liquorice plant exhibits good antioxidant activity $[11,12]$. Determination of free radical scavenging activity in the study was done by 2, 2-diphenyl-1picrylhydrazyl (DPPH) method. The different concentrations of liquorice were compared with standard ascorbic acid and it was found that the free radical scavenging activity of liquorice was higher than the ascorbic acid at higher concentration of liquorice such as 500 and $1000 \mathrm{mg} / \mathrm{ml}$, and on decreasing the concentration the free radical scavenging activity was found to be less as compared to ascorbic acid which are similar to results as reported earlier by Gaitry C. et al., 2013 [2].

The ferric reducing power antioxidant assay (FRAP) assay was also carried out to measure, the reduction of $\mathrm{Fe}^{+}$to $\mathrm{Fe} 2^{+}$by donating an electron. It was observed that increase in the concentration of liquorice increased the reducing power as compared with ascorbic acid. To further confirm the presence of polyphenolic compound LCMS was carried out, and the presence of eight different known polyphenolic compounds (Liquiritin, Isoliquiritin, Liquiritigenin, Formonetin, Glabridin, Glabrol, Glycyrrhizin, Hispaglabridin-B) was confirmed by LC-MS. Similar findings have been reported earlier by Mohammad AF. 2012 [24]. The isoflavones, glabridin and hispaglabridin A and B which were confirmed by LC-MS analysis have significant antioxidant activity and both glabridin and glabrene possess estrogen-like activity [26]. Glycyrrhizin and glabridin inhibit the generation of reactive oxygen species (ROS) by neutrophils at the site of inflammation [27]. Thus the presence of these compounds in the methanolic extract account for the antioxidant properties of liquorice.

Liquorice extract was evaluated for malondialdehyde production, catalase activity and glutathione reductase activities in HepG2 cells in treated (liquorice, $\mathrm{H}_{2} \mathrm{O}_{2}$, ascorbic acid, $\mathrm{H}_{2} \mathrm{O}_{2}$ +liquorice and $\mathrm{H}_{2} \mathrm{O}_{2}+$ ascorbic acid) and control groups. The results indicated that the $\mathrm{H}_{2} \mathrm{O}_{2}$ treated cells exhibited maximum MDA production, lower catalase and glutathione reductase level as compared to other groups, indicating that $\mathrm{H}_{2} \mathrm{O}_{2}$ treated group undergoes lipid peroxidation. Catalase activity was found to be similar in liquorice treated group and ascorbic acid-treated group.

Glutathione is an essential water-soluble antioxidant it is synthesized from the amino acids glycine, glutamate and cysteine. Glutathione can directly neutralize ROS such as lipid peroxides. Glutathione system includes glutathione, glutathione reductase, glutathione peroxidase and glutathione S-transferases [21]. We observed increased levels of glutathione reductase in liquorice treated groups as compared to other groups. Thus it is evident from our results that liquorice exhibits high antioxidant activity which is due to the presence of several polyphenolic compounds as well as high glutathione reductase and catalase activity.

\section{CONCLUSION}

In conclusion, our study has reported that liquorice extract has comparable antioxidant activity with standard ascorbic acid. These results are further validated by LC-MS analysis which confirms the presence of eight different polyphenolic compounds. Thus, liquorice can be used as a natural antioxidant source, which can be used as 
natural supplements to combat the oxidative stress in various diseases post it's validation at the in vivo level.

\section{ACKNOWLEDGMENT}

This work was supported by Symbiosis Centre for Research and Innovation (SCRI) and Symbiosis School of Biomedical Sciences (SSBS), Symbiosis International University (SIU), Lavale, Pune, India. We would like to thank B Santhakumari, Principal Scientist, CMC Division, National Chemical Laboratory (NCL) for giving permission and supporting to carry out LC-MS analysis of the plant extract.

\section{CONFLICTS OF INTERESTS}

\section{Declared none}

\section{REFERENCES}

1. Karami Z, Mirazaei H, Emam-Djomeh Z, Sadeghi M, Khomeiri. Effect of harvest time on antioxidant activity of Glycyrrhiza glabra root extract and evaluation of its antibacterial activity. Int Food Res J 2013;20:2951-7.

2. Gaitry C PKP, Binda DS, Farhin I, Sujata SD. Antimicrobial and antioxidant activities of methanol extract roots of Glycyrrhiza glabra and HPLC analysis. Int J Pharm Pharm Sci 2013;5:975-1491.

3. Stefania DA, Alessandra M, Anna S, Vincenzo Z, Patrizia G. Protective effect of polyphenols from Glycyrrhiza glabra against oxidative stress in caco-2 cells. J Med Food 2009;12:1326-33.

4. Shapna S, Afroza H, Kaiser H, Kaniz FU, Sumon R. Antimicrobial, cytotoxic and antioxidant activity of methanolic extract of Glycyrrhiza glabra. Agric Biol J North Am 2010;1:957-60.

5. Neeti S, Ajinkya AS, Ashwin VW. Polyphenol composition and in vitro antioxidant activity of Prunus amygdalus as affected by sprouting. Asian J Agric Food Sci 2014;2:349-53.

6. Vijay SJ, Santosh KS, Pankaj K, Ashish KS. Recent pharmacological trends of Glycyrrhiza glabra Linn. Int J Pharm Frontier Res 2010;1:170-85.

7. Geou Yarh L, Peter S. Reactive oxygen species in cancer. Free Radical Res 2010;44:2-30.

8. Maria AM, Sonia R, Raquel M, Ana B, Maria I, Laura B, et al. Protection of human HepG2 cells against oxidative stress by the cocoa phenolic extract. J Agric Food Chem 2008;56:7765-72.

9. Jaeschke H, Gores GJ, Cederbaum AI, Hinson JA, Pessayre D, Lemasters JJ. Forum mechanisms of hepatotoxicity. Toxicol Sci 2002;65:166-76.

10. Aparadh VT, Naik VV, Karadge BA. Antioxidative properties (TPC, DPPH, FRAP, metal chelating ability, reducing power and TAC) within some cleome species. Ann Bot 2012;2:49-56.

11. Hatano T, Edamatsu R, Mori A, Fujita Y, Yasuhara T, Yoshida T, et al. Effects of the interaction of tannins with co-existing substances. VI. Effects of tannins and related polyphenols on superoxide anion radical, and on 1,1+diphenyl+pierylhydrazyl radical. Chem Pharm Bull 1989;37:2016-21.

12. Neeti $S$, Ajinkya $S$, Ashwin W. Onion and ginger sprouting is associated with increased antioxidant activity. Int J Biol Med Res 2014;5:4586-9.

13. Asan M, Karakoca K. Evaluation of biological activity and antioxidant capacity of turkish liquorice root extracts. Rom Biotechnol Lett 2014;19:8994-9005.
14. Ibrahim K, Laurian V, Doina L, Ndreia C, Bianca I, Mihailoan L. HPLC-MS study of phytoestrogens from Glycyrrhiza glabra. Farmacia 2010;58:89-94.

15. Jiying J, Shuna Y, Zhengchen J, Cuihong L, Wenbo Y, Jin L, et al. Nacetyl-serotonin protects HepG2 cells from oxidative stress injury induced by hydrogen peroxide. Hindawi Publishing Corporation Oxidative Medicine and Cellular Longevity 2014;310504:1-15.

16. Kerman M, Senol N. Oxidative stress in hippocampus induced by $900 \mathrm{MHz}$ electromagnetic field emitting mobile phone: protection by melatonin. J Biomed Res 2012;23:147-51.

17. Akerboom TP, Sies H. Assay of glutathione, glutathione disulfide, and glutathione mixed disulfides in biological samples. Methods Enzymol 1981;77:373-82.

18. Jingxiang $B$, Ana M, Rodriguez J, Andres Me, Arthur I Overexpression of catalase in cytosolic or mitochondrial compartment protects HepG2 cells against oxidative injury. J Biol Chem 1999;274:26217-24

19. Nielsen F, Mikkelsen BB, Nielsen JB, Andersen HR, Grandjean P. Plasma malondialdehyde as biomarker for oxidative stress: reference interval and effects of life-style factors. Clin Chem 1997;43:1209-14.

20. Cingi CC, Utuk AE, Karafakioglu YS, Balkaya I, Piskin FC, Fidan AF. Serum lipid and protein oxidation and antioxidant status in horses naturally infected with theileriaequi. Rev Med Vet 2012;163:183-6.

21. Anderson ME. Glutathione: an overview of biosynthesis and modulation. Chem Biol Interact 1998;111:1-14.

22. Danyelle M Townsend, Kenneth DT, Haim T. The importance of glutathione in human disease. Biomed Pharmacother 2003;57:145-55.

23. Roth K. Liquorice spirals. Chem Unserer Zeit 2004;38:202-7.

24. Mohamed AF, Andrea P, Ludger A, Wessjohann. Comparative metabolite profiling and fingerprinting of medicinal liquorice roots using a multiplex approach of GC-MS, LC-MS and 1D NMR techniques. J Phytochem 2012;76:60-72.

25. Stevens JF, Taylor AW, Nickerson GB, Ivancic M, Henning J, Haunold A, et al. Prenylflavonoid variation in Humulus lupulus: distribution and taxonomic significance of xanthogalenol and 4'-0-methylxanthohumol. Phytochemistry 2000;53:759-75.

26. Rohit K, Hemraj, Gurpreet S, Avneet G, Sunny J, Anil J. Pharmacological activities on Glycyrrhiza glabra-a review. Asian J Pharm Clin Res 2012;6:5-7.

27. Vibha JB, Choudhary K, Mangal S, Rathore MS, Shekhawat NS. Botany research international. A study on pharmacokinetics and therapeutic efficacy of Glycyrrhiza glabra. Miracle Med Herb 2009;2:157-63.

28. Joshipura KJ, Hu FB, Manson JE. The effect of fruit and vegetable intake on risk for coronary heart disease. Ann Intern Med 2001;134:1106-14

29. Sharma N. Free radicals, antioxidants and disease. Biol Med 2014;6:1-6.

\section{How to cite this article}

- $\quad$ Dasharath B Shinde, Santosh S Koratkar, Neeti Sharma, Ajinkya A Shitole. Antioxidant activity and antiproliferative action of methanolic extract of liquorice (Glycyrrhiza glabra) in HEPG2 cell line. Int J Pharm Pharm Sci 2016;8(9):293-298. 